\title{
THE EFFECT OF ADJUVANTS AND REDUCED RATES OF CROP PROTECTION AGENTS ON WEED INFESTATION, HEALTH AND LODGING OF SPRING BARLEY (Hordeum sativum L.)
}

\author{
Cezary A. Kwiatkowski, Marian Wesołowski
}

\author{
University of Life Sciences, Department of Herbology and Plant Cultivation Techniques, Akademicka 13, 20-950 Lublin, Poland \\ e-mail: czarkw@poczta.onet.pl
}

Received: 10.07.2011

\section{Abstract}

A field experiment in the cultivation of spring barley was carried out in the period 2007-2009 at the Experimental Farm in Czesławice (central Lublin region) on grey-brown podzolic soil derived from loess (soil quality class II). The study involved 3 rates of herbicides, growth retardant and fungicides $(100 \%, 75 \%, 50 \%)$ as well as different adjuvant types (oil, surface-active, mineral adjuvant). Plots without any adjuvant were the control treatment. Conventional tillage was used, while mineral fertilization was adjusted to high initial soil nutrient availability.

A hypothesis was made that the reduction of pesticide rates by $25-50 \%$, with the simultaneous addition of adjuvants, would allow health, weed infestation and lodging of spring barley to be maintained at a level similar to that obtained under the conditions when maximum rates are applied without any adjuvant. It was also assumed that particular adjuvants could show different interactions with the tested groups of crop protection agents. It was proved that the application of full recommended rates of pesticides gave the best values of the indicators relating to weed infestation, health and lodging of spring barley. However, thanks to the addition of adjuvants to the spray solution, the application of pesticide doses reduced by $25 \%$ produced similar results. A higher reduction of pesticide rates (by 50\%) had an adverse effect on the traits in question. In such case, there was noted higher weed infestation of the spring barley crop, compensation of some weed species, and increased stem-base infection by the fungal disease complex. On the other hand, less radical changes were observed in the case of spring barley lodging. The above-mentioned situation occurred in spite of the fact that the action of pesticides was aided by adjuvants. From the group of adjuvants under comparison, the oil adjuvant Atpolan 80 EC showed the best interaction with the crop protection agents under consideration.

Key words: spring barley, pesticide rates, adjuvants, weed infestation, stem-base disease index, lodging

\section{INTRODUCTION}

A trend towards a reduction in the use of crop protection agents by $25 \%$ up to $50 \%$ has been observed in many countries in recent years. This is associated with attempts to reduce the amount of biologically active substances introduced every year into crop fields in the form of pesticides (P r a c z y k, 2001; W o ź n i c a , 2003). Lowering doses of crop protection agents used involves the risk of decreased grain yields or deteriorated grain quality as a result of crop lodging, increased weed infestation, or increased plant diseases caused by fungal pathogens ( $\mathrm{Pa}$ w $\mathrm{low}$ s k a et al. 1999; $\mathrm{W}$ e s o ł o w s ki et al. 2005). In order to prevent these consequences, it is advisable to improve the effectiveness of the performance of reduced rates of pesticides by combining them with adjuvants. These are biologically inactive substances used as aiding agents. They lower the surface tension of the spray solution, improve the uniform coverage of the leaf surface, facilitate better uptake of pesticides by the plant and their penetration into it, increase adhesion of the spray solution to the plant surface, and prevent crop protection sprays from being washed away by rain. Some adjuvants increase the weight of spray drops and thus reduce their movement by the wind or air currents $(\mathrm{Nalewaja}$ et al. 1996; Gaskin et al. 2000; Woźnica et al. 2003 , 2004). The addition of adjuvants to the spray liquid improves the effectiveness of the treatment eliminating agricultural pests and can compensate the reduced dose of an active substance (K o z i a r a , 2004; Kierzek and Ratajkiewicz, 2004).

Most adjuvants are products intended for use mainly with herbicides, and only few of them can be applied with other plant protection agents ( $\mathrm{Hol}$ low a y et al. 2000). The application of lower doses 
of chemicals serves to maintain the intensity of infestation by an agricultural pest at a level at which its harmfulness does not exceed the threshold of economic harmfulness, that is, it does not pose a threat to crops and does not cause losses of economic importance (Pr a c z y k, 2001; W o źn i c a, 2003).

In the present study, a hypothesis was made that the reduction of pesticide rates by $25-50 \%$, with the simultaneous addition of adjuvants, would allow health, weed infestation and lodging of spring barley to be maintained at a level similar to that obtained under the conditions when maximum rates are applied without any adjuvant.

The aim of the present study was to determine the effect of reduced rates of herbicides, fungicides and growth retardant as well as three adjuvant types on selected indicators for spring barley health, weed infestation, and lodging.

\section{MATERIALS AND METHODS}

The field experiment in the cultivation of spring barley (Hordeum sativum L.), cv. 'Justina', was carried out in the period 2007-2009 at the Czesławice Experimental Farm belonging to the University of Life Sciences in Lublin. It was set up as a split-block design with 3 replications, in $27 \mathrm{~m}^{2}$ plots. The experiment was established on grey-brown podzolic soil derived from loess, classified as good wheat complex. Sugar beet was the forecrop for spring barley. Mineral fertilization, adjusted to high soil nutrient availability, was applied at the following rates, calculated on a per hectare basis: $\mathrm{N}-60 \mathrm{~kg} ; \mathrm{P}_{2} \mathrm{O}_{5}-50 \mathrm{~kg} ; \mathrm{K}_{2} \mathrm{O}-80 \mathrm{~kg}$. The study investigated the following types of adjuvants: $\mathrm{A}-\mathrm{con}$ trol treatment (without any adjuvant); B - surface-active adjuvant Break Thru S $240\left(1.51 \times \mathrm{ha}^{-1}\right)$; C - oil adjuvant Atpolan $80 \mathrm{EC}\left(1.5 \mathrm{l} \times \mathrm{ha}^{-1}\right)$; D - mineral adjuvant - ammonium sulphate $\left(10 \%\right.$ solution $-1.51 \times$ ha $\left.^{-1}\right)$, as well as 3 rates of herbicides, growth retardant, and fungicides $(100 \%, 75 \%$, and $50 \%)$. The following pesticides were applied: herbicides Chwastox Turbo 340 SL (active substance MCPA + dicamba) + Puma Uniwersal $069 \mathrm{EW}$ (fenoxaprop-P-ethyl + mefenpyr-diethyl) $-2.0+1.01 \times \mathrm{ha}^{-1}$ (100\% rate), $1.5+0.751 \times \mathrm{ha}^{-1}$ (75\% rate), $1.0+0.51 \times \mathrm{ha}^{-1}(50 \%$ rate $)-$ in the spring at the tillering stage $\mathrm{BBCH} 27-28$; growth retardant (Cerone 480 SL 460 SL - ethephon) $1.01 \times$ ha $^{-1}$ (100\% rate), $0.751 \times \mathrm{ha}^{-1}$ (75\% rate), $0.51 \times \mathrm{ha}^{-1}$ (50\% rate) at the stem elongation stage $\mathrm{BBCH}$ 31-32; fungicides Tilt Plus 400 EC (propiconazole + fenpropidin) and Alert 375 SC (flusilazole + carbendazim) at identical rates $-1.01 \times \mathrm{ha}^{-1}\left(100 \%\right.$ rate), $0.751 \times \mathrm{ha}^{-1}$ (75\% rate), and $0.51 \times \mathrm{ha}^{-1}$ (50\% rate). The fungicide Alert $375 \mathrm{SC}$ was applied at the stem elongation stage BBCH 31-32, whereas Tilt Plus 400 EC at the stage BBCH 35-36.
The crop protection agents were applied using a field sprayer under a pressure of $0.25 \mathrm{MPa}$.

The infection of barley plants by the stem-base disease complex was determined at the tillering stage (BBCH 28) and at the milk stage (BBCH 75). 50 plants were pulled out from each plot. After washing away the soil, the plants were divided, depending on the degree of stem-base infection, into groups according to the below scale:

\begin{tabular}{cc}
\hline Level of infection & $\%$ of the infected stem base \\
\hline I & $1-10$ \\
II & $11-25$ \\
III & $26-50$ \\
IV & $51-75$ \\
V & $76-100$ \\
\hline
\end{tabular}

Subsequently, the disease index was calculated for stem-base diseases in accordance with Mc Kinney's formula given by $Ł$ a c i c o w a (1969).

Assessment of weed infestation of the spring barley crop was made at the dough stage $(\mathrm{BBCH}$ 83-85) using the botanical gravimetric method in test plots of $1 \times 0.5 \mathrm{~m}$, with two replications in each plot. Lodging of spring barley was estimated several days before harvest, using a 9-point scale.

The obtained results were statistically analysed using the analysis of variance and determining the significance of differences by Tukey's test $(p=0.05)$.

\section{RESULTS AND DICUSSION}

Infection of the spring barley plants by the stem-base disease complex at the tillering stage was low and ranged 2-5\% (Table 1). It should be clearly indicated that at this growth stage the individual treatments differed only in the application of herbicide doses with adjuvants.

At the milk stage of spring barley, the application of the recommended (100\%) rates of crop protection agents resulted in the stem-base disease index at a level of $12.3 \%$, irrespective of the adjuvant (Table 2). The reduction of pesticide rates by $1 / 4$ and $1 / 2$ caused an increase in the spring barley stem-base disease index by, respectively, 4.8 and 13.2 percentage points. At the same time, the statistical analysis showed significant differences in stem-base infection of spring barley both between the treatments with $100 \%$ and $75 \%$ pesticide rates and between the treatments with $75 \%$ and $50 \%$ pesticide rates, irrespective of the adjuvant.

The addition of adjuvants to the spray solution, irrespective of the pesticide rate, contributed to a significant decrease in the stem-base disease index (on average by 8.3 percentage points) relative to the control plots. The statistically proven highest 
stem-base infection of the barley plants by the fungal disease complex was found in the case when the pesticide rates had been reduced by $1 / 2$ and no adjuvant had been added to the spray solution.

The average number of weeds in the plots where the pesticide doses had been reduced by half was more than 5 times higher than in the case of application of $100 \%$ rates and nearly 4 times higher compared to that recorded in the case of the rate reduced by $25 \%$ (Table 3 ). The addition of adjuvants to the spray solution, irrespective of the pesticide rate, allowed a significant reduction in the number of weeds in the crop, respectively by $39 \%$ (Atpolan 80 EC), 34\% (Break Thru S 240), and 29\% (ammonium sulphate). Among the adjuvants under comparison, Atpolan 80 EC contributed to a significant decrease in the number of weeds in the crop (on average by 14\%), compared to the mineral adjuvant. The significantly highest number of weeds in the spring barley crop was found when no adjuvant had been applied and the rates of crop protection agents had been reduced by $50 \%$.

The highest air-dry weight of weeds in the spring barley crop was determined in the plots where the pesticide rates reduced by $50 \%$ had been applied, irrespective of the adjuvant (Table 4). It was nearly 13 times higher relative to the treatments with the $75 \%$ rate and more than 22 times higher compared to the $100 \%$ rate. The reduction of rates of crop protection agents by $50 \%$, with no adjuvant, resulted in a significant increase in air-dry weight of weeds $\left(75.4{\mathrm{~g} \times \mathrm{m}^{-2}}^{-2}\right.$. The addition of adjuvants to the $50 \%$ pesticide rate

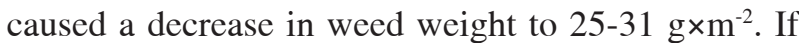
the other pesticide rates were aided by adjuvants, the level of weed infestation of the cereal crop remained at a minimal level, in the range of $1.2-3.1{\mathrm{~g} \times \mathrm{m}^{-2}}^{2}$ Regardless of the spray liquid rate, the application of all three adjuvants resulted in a significant, more than twofold (Break Thru S 240, ammonium sulphate), and even threefold (Atpolan $80 \mathrm{EC}$ ), reduction of in-crop weed biomass compared to the control treatment.

A significant positive correlation was proved between air-dry weight of weeds and the incidence of fungal diseases damaging the stem base of spring barley at the milk stage in the treatment with the pesticide rates reduced by $1 / 2$, irrespective of the addition of adjuvant. A significant positive correlation was also found between these traits in the case when the pesticide rates had been reduced by $25 \%$ and no adjuvant had been applied (Table 5).

The following weed species were predominant in the spring barley crops: Viola arvensis, Stellaria media, Chenopodium album, and Capsella bursa-pastoris, but greater species diversity and, at the same time, a lower total number of weeds were observed in the plots with the maximum pesticide rate. The reduction of rates of crop protection agents to $75 \%$ and $50 \%$ contributed to significantly lower species diversity relative to the $100 \%$ rate. Moreover, lowering the pesticide doses by half promoted the compensation of the dominant species in the crop, in particular the following: Viola arvensis, Stellaria media, Capsella bursa-pastoris, Galium aparine, Galeopsis tetrahit (Table 6).

Table 1.

Disease index for spring barley stem-base infection by the fungal disease complex (plants at the tillering stage) - mean for 2007-2009

\begin{tabular}{lcccc}
\hline \multicolumn{1}{c}{ Treatment } & \multicolumn{3}{c}{ Pesticide rate } & \multirow{2}{*}{ Mean } \\
\cline { 2 - 4 } & $100 \%$ & $75 \%$ & $50 \%$ & 4.3 \\
A - Without adjuvant (control treatment) & 3.6 & 4.2 & 5.0 & 4.9 \\
B - Break Thru S 240 - surface-active adjuvant & 3.2 & 3.9 & 4.5 & 3.9 \\
C - Atpolan 80 EC - oil adjuvant & 2.1 & 2.6 & 3.9 & 2.9 \\
D - Ammonium sulphate - mineral adjuvant & 3.5 & 4.2 & 4.4 & 4.0 \\
\hline Mean & 3.1 & 3.7 & 4.4 & - \\
\hline LSD (0.05) for: rates = not significant; adjuvants = not significant & & & & \\
\hline
\end{tabular}

Table 2.

Disease index for spring barley stem-base infection by the fungal disease complex (plants at the milk stage) - mean for 2007-2009

\begin{tabular}{lcccc}
\hline \multicolumn{1}{c}{ Treatment } & \multicolumn{3}{c}{ Pesticide rate } & Mean \\
\cline { 2 - 4 } & $100 \%$ & $75 \%$ & $50 \%$ & \\
\hline A - Without adjuvant (control treatment) & 13.6 & 23.8 & 36.2 & 24.5 \\
B - Break Thru S 240 - surface-active adjuvant & 12.4 & 15.6 & 22.3 & 16.8 \\
C - Atpolan 80 EC - oil adjuvant & 10.2 & 13.1 & 20.8 & 14.7 \\
D - Ammonium sulphate - mineral adjuvant & 12.9 & 16.0 & 22.7 & 17.2 \\
\hline Mean & 12.3 & 17.1 & 25.5 & - \\
\hline LSD (0.05) for: rates $=2.24 ;$ adjuvants $=2.04$ & & & & \\
interaction: rate $\times$ adjuvant $=8.14$ & & & & \\
\hline
\end{tabular}


Table 3.

Number of weeds in the spring barley crop per $1 \mathrm{~m}^{2}$ [pcs] - mean for 2007-2009

\begin{tabular}{lcccc}
\hline \multicolumn{1}{c}{ Treatment } & \multicolumn{3}{c}{ Pesticide rate } & \multirow{2}{*}{ Mean } \\
\cline { 2 - 5 } & $100 \%$ & $75 \%$ & $50 \%$ & 40.4 \\
A - Without adjuvant (control treatment) & 15.1 & 23.7 & 82.4 & \\
B - Break Thru S 240 - surface-active adjuvant & 10.2 & 18.2 & 51.9 & 26.8 \\
C - Atpolan 80 EC - oil adjuvant & 8.8 & 15.8 & 49.6 & 24.7 \\
D - Ammonium sulphate - mineral adjuvant & 11.7 & 19.0 & 55.6 & 28.8 \\
\hline Mean & & & & \\
\hline LSD (0.05) for: rates $=2.68 ;$ adjuvants $=3.06$ & & & & \\
interaction: rate $\times$ adjuvant $=9.24$ & & & & \\
\hline
\end{tabular}

Table 4.

Air-dry weight of weeds in the spring barley crop per $1 \mathrm{~m}^{2}$ [g] - mean for 2007-2009

\begin{tabular}{|c|c|c|c|c|}
\hline \multirow{2}{*}{ Treatment } & \multicolumn{3}{|c|}{ Pesticide rate } & \multirow{2}{*}{ Mean } \\
\hline & $100 \%$ & $75 \%$ & $50 \%$ & \\
\hline A - Without adjuvant (control treatment) & 2.4 & 3.9 & 75.4 & 27.2 \\
\hline B - Break Thru S 240 - surface-active adjuvant & 1.9 & 2.8 & 28.6 & 11.1 \\
\hline $\mathrm{C}-$ Atpolan $80 \mathrm{EC}-$ oil adjuvant & 1.2 & 2.5 & 25.4 & 9.7 \\
\hline D - Ammonium sulphate - mineral adjuvant & 1.8 & 3.1 & 31.3 & 12.1 \\
\hline Mean & 1.8 & 3.1 & 40.2 & - \\
\hline
\end{tabular}

Table 5.

Simple correlation coefficient (r) between air-dry weight of weeds and stem-base disease index at the milk stage - mean for 2007-2009

\begin{tabular}{lccc}
\hline \multicolumn{1}{c}{ Treatment } & \multicolumn{3}{c}{ Pesticide rate } \\
\cline { 2 - 4 } & $100 \%$ & $75 \%$ & $50 \%$ \\
\hline A - Without adjuvant (control treatment) & 0.25 & $0.60^{*}$ & $0.83^{*}$ \\
B - Break Thru S 240 - surface-active adjuvant & 0.11 & 0.22 & $0.58^{*}$ \\
C - Atpolan 80 EC - oil adjuvant & 0.08 & 0.19 & $0.56^{*}$ \\
D - Ammonium sulphate - mineral adjuvant & 0.16 & 0.34 & $0.65^{*}$ \\
\hline
\end{tabular}

*significant correlation coefficient (0.05)

Table 6.

Dominant weed species in the spring barley crop per $1 \mathrm{~m}^{2}$ [pcs], irrespective of adjuvants - mean for 2007-2009

\begin{tabular}{|c|c|c|c|c|}
\hline \multirow{2}{*}{ Species } & \multicolumn{3}{|c|}{ Pesticide rate } & \multirow{2}{*}{ Mean } \\
\hline & $100 \%$ & $75 \%$ & $50 \%$ & \\
\hline Chenopodium album $\mathrm{L}$. & 2.3 & 2.8 & 5.4 & 3.5 \\
\hline Viola arvensis Murray & 2.1 & 3.0 & 11.8 & 5.6 \\
\hline Stellaria media (L.) Vill & 2.0 & 3.9 & 10.3 & 5.4 \\
\hline Echinochloa crus-galli (L.) P. Beauv & 0.8 & 1.8 & 2.7 & 1.7 \\
\hline Polygonum lapathifolium L. & 0.7 & 1.1 & 2.3 & 1.4 \\
\hline Galinsoga parviflora Cav. & 0.7 & 0.9 & 3.3 & 1.6 \\
\hline Capsella bursa-pastoris (L.) Medik & 0.5 & 1.7 & 7.7 & 3.3 \\
\hline Matricaria maritima ssp. inodora (L.) Dostál & 0.4 & 0.9 & 3.4 & 1.6 \\
\hline Galeopsis tetrahit $\mathrm{L}$. & 0.3 & 0.6 & 3.8 & 1.6 \\
\hline Galium aparine $\mathrm{L}$. & 0.2 & 0.5 & 5.1 & 1.9 \\
\hline Fallopia convolvulus (L.) Á. Löve & 0.1 & 0.5 & 1.4 & 0.7 \\
\hline Lapsana communis L. S Str. & 0.1 & 0.3 & 1.0 & 0.4 \\
\hline Apera spica-venti (L.) P. Beauv. & 0.1 & 0.6 & 1.2 & 0.6 \\
\hline Other species & 1.1 & 0.6 & 0.5 & 0.7 \\
\hline Number of species & 18 & 15 & 14 & - \\
\hline LSD $(0.05)$ for: rates $=1.7$ & & & & \\
\hline
\end{tabular}


Table 7.

Spring barley lodging in a 1-9 scale - mean for 2007-2009

\begin{tabular}{|c|c|c|c|c|}
\hline \multirow{2}{*}{ Treatment } & \multicolumn{3}{|c|}{ Pesticide rate } & \multirow{2}{*}{ Mean } \\
\hline & $100 \%$ & $75 \%$ & $50 \%$ & \\
\hline A - Without adjuvant (control treatment) & 7.9 & 6.5 & 5.7 & 6.7 \\
\hline B - Break Thru S 240 - surface-active adjuvant & 8.5 & 7.6 & 6.8 & 7.6 \\
\hline $\mathrm{C}$ - Atpolan $80 \mathrm{EC}$ - oil adjuvant & 9.0 & 8.2 & 7.7 & 8.3 \\
\hline D - Ammonium sulphate - mineral adjuvant & 8.1 & 7.2 & 6.5 & 7.3 \\
\hline Mean & 8.4 & 7.4 & 6.7 & - \\
\hline LSD $(0.05)$ for: rates $=0.86 ;$ adjuvants $=0.81$ & & & & \\
\hline
\end{tabular}

* 1 - complete lodging of the crop; 9 - no lodging

The analysis of the obtained results shows that extreme reduction (by 50\%) of pesticide rates applied in spring barley crops promotes an increase in the number and weight of weeds in the crop, compensation of some weed species, and increased incidence of fungal diseases. In the opinion of some authors (Jastrzębska et al. 2001; Praczy k, 2001), the reduction of pesticide rates generally results in a decrease in cereal productivity as a result of increased occurrence of agricultural pests and adverse changes in the crop structure. In order to prevent it, pesticides should be combined with adjuvants (Woźnica, 2003). A beneficial effect of adjuvant application has been found particularly in relation to the efficacy of herbicides, but the reduction of their rates should not exceed 33\% (W e s o łow s ki et al. 2005; Kwiat k ow s ki, 2010), which is confirmed by the results of the study under discussion.

In the case of very sensitive weeds or those that are at very early growth stages, the addition of an adjuvant does not usually produce noticeable effects (A d a mczewski and Praczyk, 1995). According to some authors, in dense crops (e.g. in cereals) the destruction of all weeds is not always necessary. It is often sufficient to reduce their occurrence by 80 $90 \%$. The remaining weed individuals will be suppressed as a result of the competitive action of the crop plant (K u d s k, 1999; W o źn i c a , 2003). In the opinion of B łas zkowski and Piech (2002) as well as Domaradzki et al. (2002), weeds that are not destroyed completely can contribute to a significant decrease in yield, increased weed infestation of subsequent crops, and the development of fungal diseases. As a matter of fact, this latter aspect is confirmed by the results of the present study, since a significant positive correlation was proved between air-dry weight of weeds in the spring barley crop and the development of stem-base diseases.

In the experiment under discussion, the pesticide rates reduced by $25 \%$, but aided by the action of an adjuvant, proved to be sufficient to effectively reduce the incidence of weeds in the spring barley crop and to prevent the development of fungal diseases attacking the stem base of this cereal plant. $75 \%$ of the rate of the growth retardant also allowed lodging of spring barley to be effectively prevented. In their experiment on potato, W a chow i a k and Ki e r ze k (2003) found fungicides to have the highest efficacy when they were applied at the full recommended rate. However, a similar fungi-killing effect was observed when a half dose of fungicides was applied with the addition of an adjuvant. Pi e k a r z y k (2005) reports that, in a field with a low level of weed infestation, rates of the herbicides Aminopielik Super 464 SL and Chisel 75 WG reduced by $25 \%$, and even $50 \%$, with the addition of adjuvants, were sufficient to control weed infestation of spring barley and its yield at a level similar to treatments in which rates recommended by the manufacturers of these herbicides were applied. In the opinion of K a p e lu s zny $(2002,2003)$ as well as $\mathrm{Hal}$ in i ar z and Kapeluszny (2010), half of the recommended rate of the herbicide Chwastox Trio 540 SL can efficiently protect spring cereals against annual weeds, provided that these weeds are at early growth stages and herbicide treatment is carried out at evening hours.

It was proved in the present study that the reduction by $50 \%$ of rates of the herbicides Chwastox Turbo 340 SL and Puma Uniwersal 069 EW resulted in a significant increase in the quantitative indicators of weed infestation and led to compensation of most of the dominant weed species, in particular Viola arvensis, Stellaria media, Capsella bursa-pastoris, and Galium aparine. Domaradzki et al. (2003) are of different opinion demonstrating that Stellaria media is very sensitive to the herbicides Starane $250 \mathrm{EC}$, Chwastox Trio $540 \mathrm{SL}$, and Granstar $75 \mathrm{DF}$, irrespective of the growth stage and herbicide rate. Galium aparine was also effectively destroyed at all growth stages by the full dose of the herbicide Starane $250 \mathrm{EC}$ as well as by rates reduced by $25 \%$ and $50 \%$.

The average value of the index of spring barley lodging, for the whole study period, depended 
significantly on the rate of crop protection agents and adjuvant type (Table 7). The application of the recommended $100 \%$ rates of pesticides (including the growth retardant) effectively protected barley against lodging, irrespective of the adjuvant type. In such case, the degree of crop lodging (in a 1-9 scale) averaged 8.4, whereas in the treatments with pesticide rates of $75 \%$ and $50 \%$ it was significantly higher, respectively by 1.0 and 1.7 points. It should be noted that the addition of adjuvants to the spray solution applied at a rate reduced by $25 \%$ guaranteed the maintenance of the degree of lodging in the spring barley crop at a level similar (or even higher - Atpolan $80 \mathrm{EC}$ ) to that obtained as a result of the application of $100 \%$ rates without any adjuvant. Irrespective of the pesticide rate, the oil adjuvant Atpolan $80 \mathrm{EC}$ had the most beneficial effect on the reduction of spring barley lodging. Under the conditions of application of this agent, the degree of crop lodging in the spring barley crop was significantly lower both compared to the control treatment (by 1.6 points) and in relation to the treatment in which ammonium sulphate was used (by $1.0 \mathrm{pts}$ ). The surface-active adjuvant Break Thru S 240 also contributed to significantly lower lodging of spring barley (on average by 0.9 pts) compared to the control plots (without any adjuvant).

The degree of spring barley lodging found in the experiment in question was similar to the average level (6.7-7.4 pts) recorded by other authors $(\mathrm{No}$ worolnik et al. 2002; Kwiatkowski, 2009). Nowak and Zbroszczyk (2005) claim that the level of chemical protection does not have a significant impact on the degree of spring barley lodging. Lodging of spring barley occurs mainly on good wheat complex soils and the degree of crop lodging increases with increasing soil nutrient availability (Now orolnik, 1999). In the present study, however, higher crop lodging of spring barley was noted in the case of the application of pesticide rates reduced by $50 \%$ compared to the maximum dose, which is reflected in the studies of Leszczyńska and Grabiński (2003) as well as Miziniak (2004).

Holloway et al. (2000) and Gaskin et al. (2000) report that the efficacy of foliar-applied pesticides is determined by an exceptionally rich set of factors. They are associated not only with different properties of chemicals and pathogens controlled, but also with variable weather conditions and technical parameters of spray treatment. An adverse pattern of one or more of these factors generally reduces spray liquid retention or absorption of the active substance of a pesticide into plant cells. In effect, the efficacy of pesticides is frequently reduced and is not very stable, in particular when they are applied within any limits of rates (K i erzek and R a tajkiew ic z, 2004).

\section{CONCLUSIONS}

1. Lowering rates of crop protection plants by $25 \%$, thanks to the application of adjuvants, did not have a significant effect on the increase in the disease index for spring barley stem-base infection by the fungal disease complex and did not also cause any visible changes in weed infestation and crop lodging.

2. The reduction of pesticide rates by $50 \%$ resulted in a clear deterioration in health of spring barley at the milk stage, contributed to an increase in the number of weeds in the crop and their dry weight as well as to compensation of the dominant weed species and to crop lodging. The addition of adjuvants did not help mitigate these tendencies.

3. The type of adjuvant played an important role in affecting some of the traits in question. Atpolan 80 EC proved to be the most beneficial adjuvant; its application resulted in the highest reduction of the number of weeds in the spring barley crop and the lowest crop lodging.

\section{REFERENCES}

Adamczewski K., Praczyk T., 1995. Rape seed oil as herbicide adjuvant in Poland. Proc. $4^{\text {th }}$ Intern. Symp. 'Adjuvants for agrochemicals'. Melbourne: 374-378.

Błaszkowski J., Piech M., 2002. Comparison of seed-borne fungal communities of naked and husked oats and barley. Phytopatol. Pol. 24: 73-74.

Domaradzki K., Praczyk T., Matysiak K., 2002. System wspomagania decyzji w integrowanej ochronie zbóż przed chwastami. / Decision support system in integrated weed control in cereals. Prog. Plant Protection/ Post. Ochr. Roślin, 42 (1): 340-348. (in Polish)

Domaradzki K., Kieloch R., Rola H., 2003. Skuteczność herbicydów w zależności od dawki i fazy rozwojowej chwastów. / The effectiveness of herbicides depending on rate and growth stage of weeds. Prog. Plant Protection/Post. Ochr. Roślin, 43 (2): 109-114. (in Polish)

Gaskin R.E., Murray R.J., Krishna H., Carpenter A., 2000. Effect of adjuvants on the retention of insecticide spray on cucumber and pea foliage. New Zeland Plant Protection, 53: 355-359.

Haliniarz M., Kapeluszny J., 2010. Wpływ obniżonej dawki herbicydu MCPA + mekoprop + dikamba na zachwaszczenie trzech odmian pszenicy jarej. / The influence of reduced herbicide dose MCPA + mecoprop + dicamba on weed infestation of three varieties of spring wheat. Prog. Plant Protection/Post. Ochr. Roślin, 50 (2): 798-802. (in Polish)

Holloway P.J., Bufler Ellis M.C., Webb D.A., Western N.M., Tuck S.R., Hayes A.L., Miller P.C.H., 2000. Effects of some agricultural tank-mix adjuvants on the deposition efficiency of aqueous sprays on foliage. Crop Protection, 19: 27-37. 
Jastrzębska M., Brzozowski J., Kurowski T.P., 2001. Reakcja pszenicy ozimej na herbicydy stosowane łącznie $\mathrm{z}$ adiuwantem i mocznikiem. Cz. 1. Ocena uszkodzeń roślin i zdrowotność. Biul. Nauk. UWM Olsztyn, 11: 115-125. (in Polish)

Kapeluszny J., 2002. Zachwaszczenie łanu zbóż jarych w warunkach zróżnicowanej gęstości siewu i oszczędnego stosowania herbicydów. / Weed infestation of spring cereals under different conditions of sowing density and reduced herbicide application. Prog. Plant Protection/Post. Ochr. Roślin, 42 (2): 484-486. (in Polish)

Kapeluszny J., 2003. Wpływ zróżnicowanej gęstości siewu i obniżonych dawek herbicydów na plonowanie zbóż jarych. / Effect of sowing densities and reduced herbicide doses on spring cereal yields. Prog. Plant Protection/Post. Ochr. Roślin, 43 (2): 718-721. (in Polish)

Kierzek R., Ratajkiewicz H., 2004. Wpływ adiuwantów i parametrów opryskiwania na retencję cieczy na liściach w wybranych roślinach jednoliściennych. / Effect of adjuvants and spray parameters on retention of liquids on selected monocotyledon foliage. Prog. Plant Protection/Post. Ochr. Roślin, 44 (2): 828-831. (in Polish)

Koziara W., 2004. Wpływ nawozów dolistnych i adiuwanta na plonowanie pszenicy ozimej. / The influence of foliar fertilization and adjuvant on winter wheat yields. Pam. Puł. 135: 91-99. (in Polish)

K u d s k P., 1999. Optimising herbicide use - the driving force behind the development of the Danish decision support system. The BCPC Conference - Weeds 3: 737-746.

Kw i a t kow sk i C., 2009. Studia nad plonowaniem jęczmienia jarego nagoziarnistego i oplewionego w płodozmianie i monokulturze. Rozprawy Naukowe UP w Lublinie 336: 117. (in Polish)

Kw i a t kow s k i C., 2010. Wpływ adiuwantów oraz zredukowanych dawek środków ochrony roślin na wskaźniki jakości technologicznej ziarna pszenicy ozimej. / Effect of adjuvants and reduced doses of pesticides on technological quality indices of winter wheat grain. Prog. Plant Protection/Post. Ochr. Roślin, 50 (2): 994-998. (in Polish)

Leszczyńska D., Grabiński J., 2003. Efektywność retardantów w zasiewach pszenicy ozimej w zależności od dawki i terminu aplikacji / Effectiveness of retardants in winter wheat depending on dose and application term. Prog. Plant Protection/Post. Ochr. Roślin, 43 (2): 775-777. (in Polish)

Łacicowa B., 1969: Metoda szybkiej oceny odporności jęczmienia na Helminthosporium sativum P. K. et B. Biul. IHAR, 3-4: 61-62. (in Polish)

Miziniak W., 2004: Biologiczna ocena retardantów w uprawie jęczmienia jarego. / Biological evaluation of retardants in spring barley. Prog. Plant Protection/Post. Ochr. Roślin, 44(2): 962-965. (in Polish)

Nalewaja J.D., Devilliers B., Matysiak R., 1996. Surfacant and salt effect glyphosate retention and absorption. Weed Research, 36: 241-247.

Nowak W., Zbroszczyk T., 2005: Wpływ poziomu ochrony i nawożenia azotem na plonowanie i zdrowot- ność trzech odmian jęczmienia jarego. / Effect of protection level and nitrogen fertilization on yielding and health of three spring barley cultivars. Prog. Plant Protection/Post. Ochr. Roślin, 45(2): 954-956. (in Polish)

Now orolnik K., 1999: Wpływ różnej intensywności technologii uprawy na plonowanie jęczmienia jarego. / The effect of different intensive technology of cultivation on spring barley yielding. Pam. Puł., 114: 283-287. (in Polish)

Noworolnik K., Najewski A., Leszczyńska D., 2002: Charakterystyka i technologia uprawy odmian jęczmienia jarego. IHAR, IUNG, COBORU, Radzików. (in Polish)

Pawłowska J., Pecio A., Bichoński A., 1999. Wpływ różnych dawek herbicydów z dodatkiem adiuwanta na odchwaszczanie, plonowanie i wartość browarną jęczmienia jarego. / The influence of different herbicide doses with adjuvant on weed control, yield and malting quality of spring barley. Prog. Plant Protection/Post. Ochr. Roślin, 39 (2): 676-679. (in Polish)

Piekarczyk M., 2005. Możliwość redukcji dawek herbicydów Aminopielik Super 464 SL i Chisel 75 WG w odchwaszczaniu jęczmienia jarego. / Potential of reduction of Aminopielik Super 464 SL and Chisel 75 WG herbicides for weed control in spring barley. Acta Sci. Pol. Agricultura, 4 (1): 89-95. (in Polish)

Praczyk T., 2001. Rozwój badań i zastosowań adiuwantów w Polsce. / Progress in research and application of adjuvants in Poland. Prog. Plant Protection/Post. Ochr. Roślin, 41 (1): 110-113. (in Polish)

Wachowiak M., Kierzek R., 2003. Wpływ dawki środka ochrony roślin, dodatku adiuwanta i wielkości kropel na efektywność zwalczania agrofagów. / Effect of methods and precision spray treatments on efficacy of agrophage control. Prog. Plant Protection/Post. Ochr. Roślin, 43 (2): 994-997. (in Polish)

Wesołowski M., Kwiatkowski C., Harasim E., 2005. Wpływ zmniejszonych dawek niektórych herbicydów na plonowanie i zachwaszczenie pszenicy ozimej. / The influence of reduced dose of some herbicides on yielding and weed infestation of winter wheat. Prog. Plant Protection/Post. Ochr. Roślin, 45 (2): 1194-1196. (in Polish)

Woźnica Z ., 2003. Współdziałanie adiuwantów a skuteczność chwastobójcza herbicydów. / Adjuvant interaction and efficacy of herbicides. Prog. Plant Protection/Post. Ochr. Roślin, 43 (1): 473-479. (in Polish)

Woźnica Z., Messersmith C.G., Nalewaja J.D., 2003. Wpływ adiuwantów na skuteczność chwastobójczą sulfosulfuronu. / Effect of adjuvants on sulfosulfuron efficacy. Zesz. Probl. Post. Nauk Rol. 490, 313-321. (in Polish)

Woźnica Z., Idziak R., Szewczyk R., 2004. Nowy, wielofunkcyjny adiuwant do herbicydów opartych na glifosacie / A new, multifunctional adjuvant for herbicides based on glyphosate. Prog. Plant Protection/Post. Ochr. Roślin, 44 (1): 531-537. (in Polish) 


\section{Wpływ adiuwantów oraz zredukowanych dawek środków ochrony roślin na zachwaszczenie, zdrowotność i wyleganie jęczmienia jarego}

\section{Streszczenie}

Doświadczenie polowe $\mathrm{z}$ uprawą jęczmienia jarego przeprowadzono w latach 2007-2009 w Gospodarstwie Doświadczalnym Czesławice (środkowa Lubelszczyzna) na glebie płowej wytworzonej z lessu (II klasa bonitacyjna). W badaniach uwzględniono 3 dawki herbicydów, antywylegacza i fungicydów $(100 \%, 75 \%, 50 \%)$ oraz rodzaj adiuwanta (olejowy, powierzchniowo-czynny, mineralny). Obiekt kontrolny stanowiły poletka bez adiuwanta. Uprawę roli prowadzono w sposób typowy, zaś nawożenie mineralne dostosowano do wysokiej wyjściowej zasobności gleby w składniki mineralne.

Przyjęto hipotezę, że obniżenie dawek pestycydów o 25-50\% z jednoczesnym dodatkiem adiuwantów pozwoli na zapewnienie poziomu zdrowotności, zachwaszczenia oraz wylegania roślin jęczmienia jarego w podobnej skali, jaką uzyskuje się w warunkach stosowania dawek maksymalnych, bez adiuwanta. Założono również, że poszczególne adiuwanty mogą wykazywać zróżnicowane współdziałanie z badanymi grupami środków ochrony roślin.

Dowiedziono, iż najkorzystniejsze wskaźniki zachwaszczenia, zdrowotności i wylegania jęczmienia jarego gwarantowała aplikacja pełnych zalecanych dawek pestycydów. Jednakże, dzięki dodatkowi adiuwantów do cieczy użytkowej, podobne rezultaty przynosiło stosowanie dawek pestycydów zredukowanych o $25 \%$. Większa redukcja dawek pestycydów (o 50\%) wpływała na niekorzystne zmiany badanych cech wynikowych. Notowano wówczas większe zachwaszczenie łanu jęczmienia jarego, kompensację niektórych gatunków chwastów oraz zwiększone porażenie podstawy źdźbła przez kompleks chorób grzybowych. Mniej radykalne zmiany zaobserwowano natomiast w przypadku wylegania roślin jęczmienia jarego. Wspomniana sytuacja występowała pomimo wspomagania działania pestycydów przez adiuwanty. Z grona porównywanych adiuwantów, najlepsze współdziałanie ze środkami ochrony roślin wykazywał preparat olejowy Atpolan 80 EC. 